\section{Bangs replace whimpers}

Gordon L. Herries Davies

The New Catastrophism: The Importance of the Rare Event in Geological History. By Derek Ager. Cambridge University Press: 1993. Pp. 231. £22.95, \$34.95.

"FASCIST!" Among street politicians that is the ultimate abuse shouted as a prelude to yet more violent leftist action. "Catastrophist!" In my early days that was the ultimate insult to be hurled at an Earth scientist who seemed to be straying outside the prevailing dogma of strict uniformitarianism. We of course accepted the reality of occasional terrestrial catastrophes. I had relished my grandmother's teenage memories of the glorious English sunsets that had followed the eruption of Krakatoa in 1883 and I had just completed the Hebridean fieldwork for my undergraduate dissertation when disaster struck at Lynmouth on 15 August 1952. But all such events were seen just as natural aberrations of only temporary significance.

We preferred to believe that what was important in geohistory was nature's long-term, gradualistic processes. The Grand Canyon was entirely a result of the Colorado River's daily removal of $x$ soil-grains over millions of years. Sedimentary strata formed in a marine environment were interpreted as the little-by-little accumulation of particles raining down on the sea bed over aeons of time. What seemed to matter was the ceaseless tick-tock of the natural clock. That the sound of the ticking was occasionally drowned by a ringing of the clock's alarm seemed immaterial.

Now all is changed. We are rewriting geohistory. Where once we saw a smooth conveyor belt, we now see a stepped escalator. Upon that escalator the treads are long periods of relative quiescence when little happens. The risers are episodes of relatively sudden change when the landscape and its inhabitants are translated into some fresh state. Even the most staid of modern geologists are invoking sedimentary surges, explosive phases of organic evolution, volcanic blackouts, continental collisions and terrifying meteoroid impacts. We live in an age of neocatastrophism.

Catastrophism was originally born during the seventeenth century in an attempt to cram some inkling of the complexity of geohistory into the pint pot represented by biblical chronology. I suspect that the catastrophists of that distant age might well find themselves far more at home in our modern departments of geology than

would their uniformitarian successors in the nineteenth century.

The late Derek Ager needs no introduction to a geological audience. For nongeologists I simply observe that he was a distinguished Anglo-Welsh stratigrapher. His stimulating book The Nature of the Stratigraphical Record, first published 20 years ago, has been widely read in two editions (a third is in the press) and

\section{IMAGE UNAVAILABLE FOR COPYRIGHT REASONS}

Earth in transition - Arizona's meteor crater, which is about $\mathbf{2 0 0}$ metres deep and $\mathbf{8 0 0}$ metres across, serves as irrefragable evidence of the importance of that sudden ut rare event".

in seven continents (some thoughtful geologist must have taken a copy to the Antarctic). His new work shares with its predecessor the qualities of originality, readability and seminality. I thoroughly recommend it. On every page we encounter as our guide an idiosyncratic (the word is intended as a compliment), hammercarrying field geologist of a type increasingly rare in the modern world. $\mathrm{He}$ tells us that his "petrological hero" is the late H. H. Read and I am reminded that at the conclusion of his final field-excursion to County Donegal, Read left his field boots atop a dry-stone wall "as a gift to posterity". Ager was another great character of the same kind.

The nature of the book is revealed best by its subtitle rather than by its title. This is no broad, airy-fairy overview of neocatastrophism. It is, rather, a feet-onthe-ground, sweat-in-the-eye encounter with an abundance of actual geological sites. Some of these sites have served to convince Ager that the rocks of our globe contain irrefragable evidence of the importance of that sudden but rare event. As a vastly experienced field-observer (at the time of his writing he had plied his hammer to the face of 57 countries) he takes us from a Norwegian landslip to pillow-lavas in New Zealand and from Arizona's meteor crater to the flysch of Hokkaido. And everywhere the message is the same. We are on an escalator, not a conveyor belt.

On page xvi, I found a sentence that reverberates inside my head: "The geological record is constantly lying to us". Is that statement true? Are rocks not utterly passive in their stony silence? Surely what we know as geohistory originates not within rocks but within the minds of their human observers. As a creation of the human intellect, our geohistories may owe more than is commonly supposed to processes acting within our own $\vec{a}$ cerebra. One of Ager's heroes is Cuvier. Was he inclined towards o catastrophic interpretations of the stratigraphical column because he had witnessed the toppling of the ancien régime? Did Lyell, that high priest of uniformitarianism, exclude catastrophe from his geological system out of selfinterest? For an affluent member of the British establishment, social upheaval could spell only personal disaster. Did Lyell therefore place his taboo upon all manner of speculation invoking revolutionary turmoil? Have today's geologists invented and espoused neocatastrophism because they have lost the self-confidence enjoyed by our forebears? Do we believe in bygone catastrophes because we hold our very existence to be threatened by a multitude of potential catastrophes ranging from mass starvation to renewed glaciation?

Ager devotes several pages to the origin of the channelled scablands of Washington State. To my regret I never met the geologist who originated the now widely accepted view that those remarkable landscapes resulted from catastrophic late-glacial flooding. Such confidence did that geologist have in his theory that he took wry satisfaction in being branded a catastrophist by those benighted uniformitarians who dismissed his startling interpretation as absurd. But what really did annoy him was the critics who misspelled his name. Now Ager has fallen into the trap laid for us so long ago by that American geologist's parents. The error is in two senses just a small point. The American geologist's name was J Harlen Bretz. The J was a given name and not an abbreviation.

Gordon L. Herries Davies, fellow emeritus of Trinity College, Dublin, is at Ballinaclough House, Ballinaclough, Nenagh, Tipperary, Ireland. 